\title{
Organizing for Digitization: A Survey
}

\section{Michael Boock \& Ruth Vondracek}

\author{
Michael Boock, Head of Technical Services \\ Oregon State University Libraries \\ 121 The Valley Library \\ Corvallis, Or 97331-4501 \\ michael.boock@oregonstate.edu \\ phone:(541) 737-9155 \\ fax: (541) 737-8224
}

Ruth Vondracek, Head of Reference \& Instruction

Oregon State University Libraries

121 The Valley Library

Corvallis, Or 97331-4501

ruth.vondracek@oregonstate.edu

(541) 737-9273

(541) 737-8224 


\title{
Organizing for Digitization: A Survey
}

Michael Boock and Ruth Vondracek

\begin{abstract}
:
How are academic libraries organizing themselves in order to engage in the selection and digitization of local collections? Are libraries creating new positions or units, setting up cross-functional collaboration among existing departments, or using a combination of these strategies? Who holds responsibility for the various activities related to digitization? The authors surveyed the Association of Research Libraries (ARL) and the Greater Western Library Alliance (GWLA) to answer these questions. In addition, we review the current organizational structure at Oregon State University Libraries (OSU Libraries).
\end{abstract}

Keywords: Digital Collections; Digital Imaging; Libraries - Organization; Digitization; Libraries-Employees

\section{$\underline{\text { Introduction }}$}

Libraries have reformatted or duplicated documents to enhance access since medieval times when monks fastidiously transcribed documents by hand. Towards the end of the twentieth century, libraries began massive microfilming projects as a means of preserving print holdings. Newspaper microfilming and digitizing projects continue to successfully reformat thousands of rare, crumbling newspapers. 
Beginning in the 1990s and accelerating rapidly in the 2000s, increasing numbers of libraries, from the largest academics to the smallest publics, have taken advantage of relatively cheap and easy-to-use technology to digitize their unique print-based holdings, including photographs, postcards, books, manuscripts, maps, and analog audio and video recordings. Notable digitization projects, such as Making of America, have digitized everything from photos and manuscripts to books and articles, and found unique and compelling means to make that material accessible. ${ }^{1}$

In spite of this, little has been published on how libraries have organized to accomplish this work, how they break down the specific roles related to digitization and where decision-making rights reside within the organization. In this article, we identify the different organizational models adopted by academic libraries to accomplish digitization. We focus on the work involved within academic libraries to digitize locally owned analog or print-based content and to create access to that content. We examine the roles and responsibilities that have emerged to accomplish digitization, the extent to which traditional library expertise has been applied to digitization efforts, and where new roles and responsibilities have emerged within academic library organizational structures.

We explore whether traditional library positions and expertise were being used by libraries for related digitization work, e.g. Are catalogers assigning metadata? Are collection development departments responsible for content selection? Another issue of interest was where the responsibility for digital imaging, legal/rights management and 
other relatively new digitization responsibilities reside within library reporting structures. Our intent was not to determine the best solution, but to understand the various ways libraries have organized for digitization efforts.

\section{Literature Review}

Roy Tennant devotes an entire chapter of Managing the Digital Library to organization and staffing. He focuses on the skills or traits employers in digital libraries need to look for in potential employees. ${ }^{2}$ He also discusses how to build an agile organization capable of taking on the work of a digital library. However, these discussions are general in nature and do not delineate specific structures or positions.

In the Digital Library: A Biography, Greenstein and Thorin provide a thorough overview of the formation and organizational structures of libraries engaged in digital programs. ${ }^{3}$ Based on a detailed survey of Digital Library Federation libraries and institutions, and extensive interviews with six of the respondents, the report examines the costeffectiveness of digital programs and "what influences have helped shape successful digital library programs.” ${ }^{4}$ They found that how libraries organize for digitization varies widely. The study did not look in depth at specific roles or responsibilities.

Kansas State University, as part of their Digital Libraries Technical Infrastructure Task Force report, identified five broad categories under which specific digital library project roles and responsibilities fall. ${ }^{5}$ These broad categories include Management, Requirements Analysis and Design, Core Technical Support, User Support, and Legal 
and Policy Issues Support. However, they do not discuss where these roles and responsibilities fall within their organization.

The authors have written previously about the impact of digitization in library organizations, described the "cast of characters" involved in digitization projects, and discussed the specific roles of library staff to accomplish digitization activities in their libraries. ${ }^{6}$ While they argue that traditional library roles and responsibilities naturally extend to digitization activities, they also suggest non-traditional blending of responsibilities across public and technical service units. ${ }^{7}$ However, neither article details the organizational structure as a whole in relation to digitization activities.

\section{The Survey \& Methodology}

We designed the 58 survey questions to help us understand the impact of digitization on library structure. Library respondents were asked the number of staff FTE (full time equivalent) employed in the library, whether the library was engaged in digitizing locally-owned print-based content, and if so, how many years the library had been involved in digitization efforts. These answers were cross tabulated against the remaining responses in order to find whether size of library and number of years involved in digitization has any effect on the way libraries organize to accomplish digitization.

Eighteen separate digitization responsibilities associated with a standard workflow design were identified, including content selection, negotiation with groups outside the library, user needs assessment, digital imaging, and metadata creation (Appendix). Libraries were 
asked to identify the department responsible for each of these responsibilities in the digitization process. The names of departments were standardized as much as possible so that generalizations could be made. Libraries were given the following choices when assigning departmental responsibility: Administration, Archives, Collection Development, Reference, Special Collections, Systems, Technical Services, Outsource/Consultant, Not applicable, and Other. If the choice of the departments did not match exactly with the department names used at the responding libraries, respondents were asked to choose the closest equivalent, for example, Technical Services instead of Acquisitions or Cataloging.

Multiple responses were accepted for most questions. Respondents were also asked to identify which departments at their institutions are involved in digitization, whether the institution has created a new position or unit to handle aspects of digitization, where those positions and units report within the library organizational structures, the names of the new positions and units, whether project groups are used and their responsibilities, whether other academic units external to the library have digitization responsibilities, and the classification level (professional, para-professional or student) of the persons with each digitization responsibility.

To answer our questions about how libraries were organized to handle digitization efforts, we surveyed Association of Research Libraries (ARL) and Greater Western Library Alliance (GWLA) libraries. ARL includes 123 research libraries. GWLA includes 31 academic and research libraries in the Western United States and the greater 
Midwest, 26 of which are also members of ARL. We selected ARL and GWLA libraries because they were easily identified and most are academic libraries engaged in digitization.

A survey link was sent via email on December 6, 2004 to the 129 selected libraries. Contacts were identified by examining each library's website and selecting the person most likely to have management responsibility for digitization initiatives at the library. If we had selected the wrong contact, we requested that the email be forwarded to the correct person at the institution. Forty of the 129 libraries responded, for a response rate of 31 per cent.

\section{$\underline{\text { Results }}$}

Libraries Involved in Digitization: Of the 40 total responding libraries, 38 (or 95\%) are currently involved in digitizing locally-owned, print-based content. Of those 38 libraries, $13 \%$ have been engaged in digitization efforts for 2 years or less, 37\% for 3-5 years (50\% for 5 years or less), and $50 \%$ for 6 years or more.

Departments Involved in Digitization: Eighty-four percent of responding libraries’ Special Collections departments are involved in digitization (Table 1). Other departments involved in digitization include Systems departments (58\% of responding libraries), Archives, and Technical Services (50\% each). Reference (21\%) and Collection Development (23\%) departments are the least involved in digitization at responding 
libraries. Thirty-nine percent of Administration departments or offices are involved in some aspect of digitization.

Table 1 -- Departments Involved in Some Aspect of Digitization Unit

Administration $\quad 39 \%$

Archives $\quad 50 \%$

Coll. Dev. $\quad 23 \%$

Reference $\quad 21 \%$

Special Coll. $\quad 84 \%$

Systems $\quad 58 \%$

Tech. Services $\quad 50 \%$

Other* $\quad 50 \%$

*Other: Newly created digital library units

Creation of New Positions: Seventy-six percent of responding libraries have created a new position to assist with digitization efforts. In most of these libraries (52\%), the new positions report to new digital library units or departments outside of the traditional library organizational structure. Ten libraries (30\%) report that a new position with digitization responsibilities reports to their Systems department and six libraries (18\%) report that a new position reports to their Special Collections department. Eighteen of 19 (95\%) engaged in digitization for 6 years or more have created new positions versus 11 of 19 (58\%) engaged in digitization 5 years or less.

The new digitization-related positions have responsibilities that fall across the range of digitization responsibilities. New positions have responsibility for digitizing (87\%), project management (84\%), metadata (77\%), web page design (74\%), digital preservation (55\%), legal/rights management (52\%), programming (52\%), and content selection (52\%). Other new digitization-related position responsibilities include grant-writing and other fund seeking, user studies, and usability testing. Examples of new digitization- 
related positions include heads of a digital initiative units or departments, digital imaging librarians and staff, copyright coordinators, and metadata specialists.

Eighty-seven percent of responding libraries that have hired a new position for digitization have hired at the professional level, and $47 \%$ have hired at the paraprofessional level. The terms professional and para-professional are defined by the responding library; no explanation was requested from the responding libraries about the requirements for each level.

Creation of New Units: Half of the responding libraries have created new units to handle aspects of digitization, 8 of which report to Administration, 2 to Special Collections departments, 3 to Systems departments, and 4 to Technical Services departments. Nine of these new units report to other, unspecified departments or outside of the traditional library reporting structure. New units, like the new positions created, have some responsibility for all aspects of the digitization process. Examples of new units created to handle aspects of digitization include digital services departments, digital imaging units, and electronic publishing centers.

Libraries engaged in digitization efforts for 6 years or more are more likely to have created new positions or new units to handle digitization. Fourteen of 19 of these libraries (74\%) have created new units versus only 5 of 19 (26\%) libraries engaged in digitization less than six years. Of those libraries engaged in digitization efforts for less than 6 years, 
responsibilities are more concentrated in Archives, Special Collections and Systems departments than those libraries engaged in digitization efforts for more than 6 years.

As digitization efforts mature, responsibilities become more mainstreamed, with greater responsibility in Technical Services, Reference and Collection Development departments. In addition, more libraries create new units to handle some aspects of digitization, most often sharing responsibilities with traditional library departments.

Cross-departmental Project Groups: Even though half of responding libraries have created new units and 76\% have created new positions with responsibilities that fall across the full range of the digitization process, $84 \%$ use cross-departmental project groups to handle aspects of digitization at their libraries. Project groups most often have responsibility for content selection (73\%), metadata (67\%), project management (57\%), and web page design (50\%). Other project group responsibilities include preservation (40\%), legal/rights management (40\%), and digitizing considerations (47\%). Half of the responding libraries report that other academic units on their campuses have some responsibility for digitization or are engaged in their own digitization efforts.

Selection: Respondents indicate that departments traditionally responsible for selection of library materials are responsible for proposing digitization of items or collections (Table 2). The departments in the responding libraries that are able to propose that items/collections be digitized include Special Collections departments (87\%), Archives departments (71\%), Collection Development departments (71\%) and Reference 
departments (58\%) Many responding libraries indicated that anyone in the library could propose digitization, but that only the above listed departments do so. This result is not surprising given that unique collections frequently reside in Special Collections and Archives and their staff is normally responsible for selection.

The longer a library has been engaged in digitizing materials, the more likely it is that selection of content or proposing specific content for digitization is done in departments traditionally responsible for selecting library materials - Special Collections, Archives, Collection Development - and the less selection is done within Systems and Technical Services, departments not traditionally associated with material selection.

Table 2 - Department Responsible for Proposing that Items Be Digitized

Unit

Administration

Archives

Coll. Dev.

Reference

Special Coll.

Systems

Tech. Services

Outsource

Not applicable

Other
Propose

$71 \%$

$71 \%$

$71 \%$

$58 \%$

$87 \%$

$34 \%$

$32 \%$

$0 \%$

$0 \%$

$39 \%$

Final approval: Final approval for digitization efforts to move forward is most often the responsibility of library administration (55\%), although several libraries indicate that the newly created digital library departments and units can give approval. Some libraries indicate that whichever department proposes digitization is authorized to approve them (Table 3).

Table 3 - Department Responsible for Giving Final Approval Unit Final Approval 
Administration $\quad 55 \%$

Archives $\quad 13 \%$

Coll. Dev. $\quad 21 \%$

Reference $\quad 3 \%$

Special Coll. $\quad 26 \%$

Systems $\quad 18 \%$

Tech. Services $\quad 3 \%$

Outsource $\quad 0 \%$

Not applicable $\quad 0 \%$

Other* $32 \%$

*Other: Newly created digital library units, proposing departments

Coordination of Digitization Efforts: The survey indicates that newly created digital

library units and departments coordinate digitization efforts (Table 4). Libraries engaged in digitization efforts for 6 years or more see a decrease in the coordination responsibilities of Special Collections, Archives, Systems and Administration. More often coordination resides with new digital library units. Again, this seems to indicate that digitization efforts begin at libraries with Special Collections, Archives, and Systems department involvement, where the unique content or technical expertise initially resides, before shifting to the new units. Responsibility for coordinating digitization efforts almost always resides with professionals (95\% of the time) at the responding libraries.

Table 4 - Department Responsible for Coordinating Digital Efforts Unit Coordination

Administration $\quad 32 \%$

Archives $\quad 11 \%$

Coll. Dev. $\quad 5 \%$

Reference $\quad 18 \%$

Special Coll. $\quad 21 \%$

Systems $\quad 8 \%$

Tech. Services $\quad 8 \%$

Outsource $\quad 0 \%$

Not applicable $\quad 0 \%$

Other* $37 \%$

*Other: Newly created digital library units 
Content Selection: Responding libraries indicate that content selection is widely dispersed and does not follow traditional library roles as much as might be expected (Table 5). Twenty-one percent of Collection Development departments have responsibility for content selection, although the figure rises for libraries engaged in digitization for 6 years or more. Much content selection may be done within project groups that have Collection Development representation. Special Collections (55\%) and Archives (32\%) departments, the departments that most frequently contribute content, are most often responsible for selecting content for digitization. All responding libraries indicated that library professionals do selection.

Table 5 - Department Responsible for Content Selection Unit Selection

Administration $\quad 18 \%$

Archives $\quad 32 \%$

Coll. Dev. $\quad 21 \%$

Reference $\quad 13 \%$

Special Coll. $\quad 55 \%$

Systems $\quad 13 \%$

Tech. Services $\quad 5 \%$

Outsource $\quad 0 \%$

Not applicable $\quad 0 \%$

Other* $50 \%$

*Other: Selection Committee charged solely with selecting collections for digitization, Unit contributing content, Digital Collections bibliographer within Administration, Newly created digital library units, project groups

Negotiation - External: Most negotiation with groups external to the library - for example, other academic units and outside agencies - is done within administration (58\%), Special Collections (45\%) or in newly created library units (Table 6). Archives and Special Collections department negotiation involvement decreases with the number of years a library is involved in digitization efforts. Library professionals handle negotiation with outside groups (97\%). 
Table 6 - Department Responsible for Negotiating with Outside Groups

Unit Negotiation

Administration $\quad 58 \%$

Archives $\quad 18 \%$

Coll. Dev. $\quad 13 \%$

Reference $\quad 5 \%$

Special Coll. $\quad 45 \%$

Systems $\quad 24 \%$

Tech. Services $\quad 11 \%$

Outsource $\quad 0 \%$

Not applicable $\quad 3 \%$

Other* 39\%

*Other: Newly created digital library units

Assessment of User Needs: User needs assessment, which may include determination of who the primary audience is likely to be, how the audience is likely to retrieve information, and what information and context the audience requires, is accomplished within Special Collections departments (58\%) or Reference departments (42\%), where it might be expected to reside (Table 7). Newly created digital library units are often responsible for user needs assessment. Reference becomes more involved in assessing user needs among libraries engaged in digitization efforts for 6 years or more. User needs assessment is done primarily at the professional level (97\%) but also by paraprofessionals at $32 \%$ of responding libraries.

Table 7 - Department Responsible for User Needs Assessment

Unit User Needs

Administration $\quad 13 \%$

Archives $\quad 26 \%$

Coll. Dev. $\quad 24 \%$

Reference $\quad 42 \%$

Special Coll. $\quad 58 \%$

Systems $\quad 21 \%$

Tech. Services $\quad 16 \%$

Outsource $\quad 3 \%$

Not applicable $\quad 3 \%$

Other* $\quad 47 \%$


*Other: Newly created digital library units, project groups, department that contributes content

Web-Interface Usability: This is either handled with Systems departments (39\%) or in newly created digital library units, cross-departmental project groups, or library web committees, with occasional Reference (21\%) or Special Collections (18\%) involvement (Table 8). Professionals are involved in web interface usability at $100 \%$ of responding libraries. Paraprofessionals have some web interface usability responsibility at 32\% of responding libraries.

Table 8 - Department Responsible for Web Interface Usability

Unit

Administration

Archives

Coll. Dev.

Reference

Special Coll.

Systems

Tech. Services

Outsource

Not applicable

Other*
Web Interface Usability

$13 \%$

$8 \%$

$5 \%$

$21 \%$

$18 \%$

$39 \%$

$13 \%$

$3 \%$

$0 \%$

$61 \%$

*Other: Newly created digital library units, cross-departmental project groups, web committees, communication offices

Metadata Activities: Cataloging or metadata related activities that traditionally reside within Technical Services or Cataloging departments continue to fall there when applied to digitization activities. Sixty-six percent of Technical Services departments at responding libraries have responsibility for selection and development of metadata structures (e.g. determination of schema, field selection, field labeling, data dictionary creation) (Table 9). Occasionally this responsibility resides with Systems departments 
(29\%). For libraries engaged in digitization activities for 6 years or more, this

responsibility is increasingly shared with newly created digital library units.

Table 9 - Department Responsible for Determining Metadata Structure

Unit Metadata Structure

Administration $\quad 5 \%$

Archives $\quad 21 \%$

Coll. Dev. $\quad 3 \%$

Reference $\quad 0 \%$

Special Coll. $\quad 32 \%$

Systems $\quad 29 \%$

Tech. Services $\quad 66 \%$

Outsource $\quad 3 \%$

Not applicable $\quad 0 \%$

Other* 39\%

*Other: Newly created digital library units, metadata steering group, metadata librarian reporting to digital library unit and Technical Services

Controlled Vocabularies: Seventy-one percent of Technical Services departments at responding libraries have responsibility for creating or selecting controlled vocabularies (Table 10). Surprisingly Collection Development (5\%) and Reference (3\%) departments, departments with subject expertise that could benefit the creation of controlled subject lists, are seldom involved.

Table 10 - Department Responsible for Controlled Vocabularies

Unit Controlled Vocabularies

Administration $\quad 5 \%$

Archives $\quad 18 \%$

Coll. Dev. $\quad 5 \%$

Reference $\quad 3 \%$

Special Coll. $\quad 26 \%$

Systems $\quad 13 \%$

Tech. Services $\quad 71 \%$

Outsource $\quad 3 \%$

Not applicable $\quad 3 \%$

Other* 32\%

*Other: Newly created digital library units, metadata librarian reporting to digital library unit and Technical Services 
Assigning Metadata: Technical Services departments at responding libraries are more often than not responsible for assigning metadata (59\%) (Table 11). Special Collections departments (46\%) also have metadata creation responsibilities. Metadata assignment, as opposed to metadata structure and controlled vocabulary development, both of which are done predominantly by professionals, is scattered among different classification levels. Professionals are responsible for some aspect of metadata assignment at all responding libraries, para-professionals at $51 \%$ of libraries, and students at $24 \%$ of libraries. Basic metadata may be done at the lower classification levels with quality control and more complex subject analysis and description being done by professionals.

Table 11 - Department Responsible for Assigning Metadata

Unit Assigning Metadata

Administration $\quad 5 \%$

Archives 24\%

Coll. Dev. $\quad 8 \%$

Reference $\quad 5 \%$

Special Coll. $\quad 46 \%$

Systems $\quad 14 \%$

Tech. Services $\quad 59 \%$

Outsource $\quad 0 \%$

Not applicable $\quad 0 \%$

Other* 57\%

*Other: Curators in each individual department enter metadata about their digital objects, into a database, decentralized metadata creation with subject specialists, newly created digital library units, metadata librarian reporting jointly to digital library unit and Technical Services

Responsibility for Digitization: Digitizing responsibilities, most often scanning but also including the digitizing of analog audio and video recordings, is done by more departments and is more widely scattered than any other digitization responsibility (Table 12). No traditional library department is responsible for digitizing in more than $35 \%$ of 
responding libraries. Special Collections departments (34\%) are most often responsible. More often, newly created digital library units are responsible. This may be because digitizing falls most outside the traditional library roles of acquiring, cataloging and enabling access to information. Metadata creation equates with the cataloging of books and other materials, selection of digital content equates with the selection of books and other formats of materials, but scanning does not closely equate with traditional library responsibilities, perhaps most closely equating with interlibrary loan photocopying and scanning activities. Yet only $18 \%$ of responding libraries outsource digitizing work, and only one Access Services (ILL, circulation, stacks management) department is responsible for digitization efforts. Library respondents indicate that employees at all classification levels are involved in digitizing, students at $51 \%$ of libraries, professionals at $59 \%$, but most often para-professionals at $71 \%$.

Table 12 - Department Responsible for Digitizing

$\begin{array}{ll}\text { Unit } & \text { Digitizing } \\ \text { Administration } & 5 \% \\ \text { Archives } & 18 \% \\ \text { Coll. Dev. } & 3 \% \\ \text { Reference } & 3 \% \\ \text { Special Coll. } & 34 \% \\ \text { Systems } & 18 \% \\ \text { Tech. Services } & 16 \% \\ \text { Outsource } & 18 \% \\ \text { Not applicable } & 0 \% \\ \text { Other* } & 50 \%\end{array}$

*Other: Newly created digital library units, copy shop, access services, preservation units

Software Installation, Maintenance and Support: Responsibilities that are traditionally aligned with Systems departments or their equivalents reside in those departments in the digitization realm as well. Software installation, maintenance and support are accomplished in Systems departments of 87\% of the responding libraries (Table 13). 
Rarely, this is handled by newly created digital library units or in Technical Services departments (21\%). Software programming - such as writing and loading scripts, creating software or building software extensions and add-ons - is largely accomplished in Systems departments (74\%), as expected, although some libraries noted that this is also accomplished in newly created digital library units or in Technical Services (16\%) (Table 14). All of the systems related work is scattered between professionals and paraprofessionals.

Table 13 - Department Responsible for Installing and Maintaining Software Unit Software

Administration $\quad 3 \%$

Archives $\quad 5 \%$

Coll. Dev. $\quad 0 \%$

Reference $\quad 0 \%$

Special Coll. $\quad 5 \%$

Systems $\quad 87 \%$

Tech. Services $\quad 21 \%$

Outsource $\quad 5 \%$

Not applicable $\quad 0 \%$

Other* 26\%

*Other: Newly created digital library units

Table 14 - Department Responsible for Programming

$\begin{array}{ll}\text { Unit } & \text { Programming } \\ \text { Administration } & 5 \% \\ \text { Archives } & 5 \% \\ \text { Coll. Dev. } & 0 \% \\ \text { Reference } & 0 \% \\ \text { Special Coll. } & 5 \% \\ \text { Systems } & 74 \% \\ \text { Tech. Services } & 16 \% \\ \text { Outsource } & 3 \% \\ \text { Not applicable } & 3 \% \\ \text { Other* } & 26 \%\end{array}$

*Other: Newly created digital library units, application programming units 
Web page design: Web page design, while residing most often in Systems (50\%), also occurs in many Special Collections (32\%), Archives (18\%) and Technical Services (18\%) departments (Table 15). Newly created digital library units also have responsibility for web page design, as do cross-departmental project groups or web committees.

Table 15 - Department Responsible for Web Page Design

Unit Web Page Design

Administration $\quad 11 \%$

Archives $\quad 18 \%$

Coll. Dev. $\quad 5 \%$

Reference $\quad 8 \%$

Special Coll. $\quad 32 \%$

Systems $\quad 50 \%$

Tech. Services $\quad 18 \%$

Outsource $\quad 5 \%$

Not applicable $\quad 0 \%$

Other* $\quad 47 \%$

*Other: Newly created digital library units, cross-departmental web teams, communication units

Preserving and Updating Content: Digital content preservation and refreshing, when done at all, is handled by Systems departments (58\%) (Table 16). Special Collections handles some aspect of digital preservation at $26 \%$ of responding libraries. Technical Services has some responsibility for digital preservation at $16 \%$ of responding libraries. Professionals (95\%) or paraprofessionals (57\%) most often handle this work.

Table 16 - Department Responsible for Preservation

$\begin{array}{ll}\text { Unit } & \text { Preservation } \\ \text { Administration } & 5 \% \\ \text { Archives } & 16 \% \\ \text { Coll. Dev. } & 3 \% \\ \text { Reference } & 0 \% \\ \text { Special Coll. } & 26 \% \\ \text { Systems } & 58 \% \\ \text { Tech. Services } & 16 \% \\ \text { Outsource } & 3 \% \\ \text { Not applicable } & 3 \% \\ \text { Other* } & 42 \%\end{array}$


*Other: Newly created digital library units, preservation units, no formal digital preservation being done

Instruction: Instruction and training of users of digitized content is accomplished by those who work at library public service points, particularly by Reference departments (74\%), Special Collections departments (37\%) and Archives departments (24\%), as well as by newly created digital library units (Table 17). Instruction and training is the responsibility of professionals at all responding libraries.

Table 17 - Department Responsible for User Instruction

Unit Instruction

Administration $\quad 3 \%$

Archives $\quad 24 \%$

Coll. Dev. $\quad 8 \%$

Reference $\quad 74 \%$

Special Coll. $\quad 37 \%$

Systems $\quad 8 \%$

Tech. Services $\quad 5 \%$

Outsource $\quad 0 \%$

Not applicable $\quad 8 \%$

Other* $32 \%$

*Other: Newly created digital library units

Promotion and Public Relations: Administration offices at $71 \%$ of responding libraries have responsibility for promotion and public relations (Table 18). Reference departments (42\%) and Collection Development departments (21\%) also hold some responsibility for promotion and public relations. Special Collections (39\%), Archives (29\%), newly created digital library units and communication offices also have this responsibility. Professionals (92\%) are most often responsible for promotional activities, although paraprofessionals also have some responsibility for this at responding libraries (49\%).

Table 18 - Department Responsible for Promoting and Public Relations Unit Promotion

Administration $\quad 71 \%$ 
Archives $\quad 29 \%$

Coll. Dev. $\quad 21 \%$

Reference $\quad 42 \%$

Special Coll. $\quad 39 \%$

Systems $\quad 11 \%$

Tech. Services $\quad 3 \%$

Outsource $\quad 0 \%$

Not applicable $\quad 3 \%$

Other* $\quad 53 \%$

*Other: Newly created digital library units, communications offices

Legal and Rights Management: This responsibility includes rights procurement (copyright permissions), intellectual property management, and licensing. Like the digitizing responsibility, it does not fall clearly into any one of the traditional library departments (Table 19). Administrative offices have this role at $42 \%$ of the responding libraries. Other library departments that take on this role include Special Collections (32\%), Archives (24\%), Systems (21\%), Collection Development (16\%) and Technical Services (16\%). Other library respondents noted that the university’s legal counsel in tandem with a newly created digital library unit, a permissions office, or a full-time attorney has some responsibility for legal/rights management.

Table 19 - Department Responsible for Rights Management

Unit Rights Management

Administration $\quad 42 \%$

Archives 24\%

Coll. Dev. $\quad 16 \%$

Reference $\quad 5 \%$

Special Coll. $\quad 32 \%$

Systems $\quad 21 \%$

Tech. Services $\quad 16 \%$

Outsource $\quad 0 \%$

Not applicable $\quad 5 \%$

Other* $37 \%$

*Other: University legal counsel, newly created digital library units, proposing units, permissions office, full-time attorney hired by library 


\section{Summary \& Conclusions}

The digitization of unique, locally owned resources in academic libraries has become increasingly widespread; all but two (38 of 40) of the libraries responding to the survey are engaged in digitization efforts and half of those began digitizing within the last five years. Organizational models vary widely among the libraries; no single type of structure appears to be the most prevalent. However, there are some commonalities identified from the survey results.

Most libraries, particularly those engaged in digitization efforts for six years or more, have created at least one new position to handle some aspect of digitization. Libraries engaged in digitization for six years or more are also more likely to have created a new unit to handle digitization activities. Survey results indicate that digitization efforts most often begin within the units that contain the materials to be digitized; for example, libraries’ Special Collections and Archives units. Over time, digitization responsibilities are either mainstreamed within library units or responsibilities are moved to new units with a full range of digitization responsibilities. The majority of libraries, even those with new units, use cross-departmental project groups in order to take advantage of expertise from across the library.

Digitization activities include a number of responsibilities found in traditional library organizational structures, such as selection and cataloging, as well as relatively new responsibilities, such as digital imaging and digital legal and rights management. The 
level of staff that is assigned to particular digitization responsibilities aligns closely with the way tasks have traditionally been assigned in libraries. Paraprofessional staff has greater responsibility for digital imaging than professionals; otherwise, professional librarians hold most digitization responsibilities.

As libraries move from analog to digital formats the biggest challenge for OSU Oregon State University (OSU) and others will be to remain agile enough organizationally to apply library competencies in an online environment. Some libraries may choose to develop new competencies while retaining a traditional structure. Others may develop new structures. Whatever choice is made, it is clear that digitization offers opportunities to take stock of how current practice fits in with future needs. Taking stock may result in a new library organization that looks completely different from the traditional divisions between technical and public services. Results from the survey indicate that there is no best way to organize for digitization efforts, so long as libraries recognize that the organization and its employee's expertise reflect the new digital reality. 


\section{$\underline{\text { Appendix }}$}

\section{Digitization Responsibilities}

1. Proposing an item or collection for digitization

2. Giving final approval for digitization efforts to move forward

3. Coordinating the efforts

4. Selecting content

5. Negotiating with groups outside the library

6. Assessing user needs (e.g. determining the audience, how the audience will search and retrieve information, what information and context the audience will require)

7. Determining web interface usability

8. Selecting and developing metadata structures (e.g. determination of schema, field selection, field labeling, and data dictionary creation)

9. Selecting and creating controlled vocabularies

10. Digitizing

11. Assigning metadata

12. Installing, maintaining and supporting software

13. Programming

14. Designing web pages

15. Training and instructing users of digital content

16. Promoting the collections and public relations

17. Legal and rights management

18. Preserving and refreshing digital content. 


\section{$\underline{\text { Endnotes }}$}

1 “Making of America”, (n.d.) http://www.hti.umich.edu/m/moagrp/ (Accessed August 12, 2005).

${ }^{2}$ Roy Tennant, Managing the Digital Library (New York, NY: Reed Press, 2004), 149169.

${ }^{3}$ Daniel Greenstein and Suzanne E. Thorin, The Digital Biography, Strategies and Tools for the Digital Library, CLIR series, (Washington, D.C.: Digital Library Association, Council on Library and Information Resources, Sept. 2002).

${ }^{4}$ Ibid: 1 .

5 “Kansas State University Digital Library Program Recommendations” (n.d.), http://www.ksu.edu/DigitaLibraries/notes/Recommendations.pdf (accessed November 2004).

${ }^{6}$ Ruth Vondracek, “Going Beyond Selection,” Library Journal netConnect, Summer 2003, (July, 15, 2003) http://www.libraryjournal.com/article/CA304093 (accessed May 2005).

${ }^{7}$ Boock, Michael, et al., “Getting Digitization Projects Done in a Medium-Sized Academic Library: A Collaborative Effort Between Technical Services, Systems, Special Collections, and Collection Management,” Technical Services Quarterly 20, 3 (2003): 19 $-31$ 
